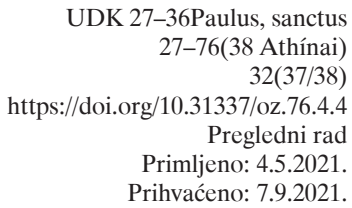

\title{
Pavao u Ateni
}

\author{
Josip Talanga*
}

\begin{abstract}
Sažetak
Tijekom svoje prve europske misije Pavao se je u Filipima i Solunu suočio s ozbiljnim optužbama. Da bi izbjegao sukob s rimskom vlašću, prekinuo je svoju misiju i prije planiranoga odlaska u Korint našao utočište u Ateni. Kao obično, uspostavio je kontakt sa židovskom zajednicom, ali nije propustio priliku da na glavnom trgu kulturnoga središta ondašnjega svijeta iznosi Evanđelje. Atena je u to vrijeme djelovala kao veliki otvoreni muzej prepun religijskih objekata, što je izazvalo Pavlovu ogorčenost zbog mnoštva idola. Svojim svakodnevnim raspravama na agori izazvao je pozornost i filozofski obrazovanih građana. Nekima je bilo čudno spominjanje Isusa i uskrsnuća — shvatili su ih kao nova božanstva. Nakon prijave morao se je opravdati pred Areopagom, koji je bio nadležan za religijska pitanja. Pavao je iskoristio priliku i održao prvu kršćansku apologiju pred dobro informiranim politeistima. Vijeće Areopaga nije našlo ništa sporno, govor je prekinut i nije podignuta nikakva optužnica.
\end{abstract}

Ključne riječi: Pavao i rimska vlast; atenska agora u Pavlovo doba; Pavao pred Areopagom

\section{Uvod}

Pavao je došao u Atenu tijekom misijskoga putovanja u Makedoniju. Sa suradnicima je krenuo iz sirijske Antiohije (vjerojatno 49. godine) preko Male Azije na zapad. Posjećivali su već postojeće kršćanske zajednice. Nisu širili evanđelje kod onih koji ga još nisu bili primili jer im to, prema Lukinim riječima, nije dopuštao Duh Sveti (Dj 16,6). ${ }^{1}$ Kada su stigli u Troadu na Egejskom moru, Pavlu se je u snu pojavio »neki čovjek Makedonac « $(\mathrm{Dj} 16,9)$, koji ga je zamolio da dođe u Makedoniju pomoći im. To su shvatili kao Božji poziv, pa su se uputili u Makedoniju. Iz Troade su brodom krenuli u Samotraku, te dalje preko lučkoga

* Prof. dr. sc. Josip Talanga, zaslužni znanstvenik u miru, Fakultet filozofije i religijskih znanosti Sveučilišta u Zagrebu. Adresa: Jordanovac 110, 10000 Zagreb, Hrvatska. ORCID iD: https:// orcid.org/0000-0001-7890-6716. E-adresa: josiptalanga@yahoo.com

1 Malo kasnije tu neobičnu zabranu ponavlja Isusov Duh (Dj 16,7).

2 Prijevode biblijskoga teksta načinio je autor rada prema grčkomu izvorniku. 
grada Neapola u rimsku koloniju Filipe. Očito su se ciljano uputili u taj grad, u prvu europsku misiju. ${ }^{3}$

U Filipima Pavao nije došao u sukob sa Židovima, nego s nekim lokalnim stanovnicima zbog istjerivanja proročkoga duha. On i njegov suradnik Sila loše su prošli — završili su u tamnici, a izvukli su se kada su se, nakon neobičnoga oslobođenja potresom, predstavili kao rimski građani. Bili su pošteđeni daljnjega kažnjavanja, ali su zamoljeni napustiti grad. Što se je dogodilo? Jedna ropkinja, koja je u sebi imala pitijski duh ${ }^{4}$ (Dj 16,16), svakodnevno je glasno vikala za Pavlom i Silom da su sluge najvišega boga i da navješćuju put spasenja. To je Pavla naljutilo, pa je taj duh doslovno istjerao iz ropkinje i ona je izgubila svoj proročki dar. Uvrijeđeni vlasnici ropkinje odvukli su ih na gradski trg pred lokalnu vlast (Dj 16,19) i optužili za običaje nedostojne Rimljana. Time su počele teškoće koje su Pavla na koncu dovele u atensko utočište. Čini se prima facie kao da je ropkinja u javnosti govorila istinu o Pavlu i Sili, pa je čudno zašto je Pavao tako reagirao. No ropkinja ih je vjerojatno povezala s religioznom skupinom koja

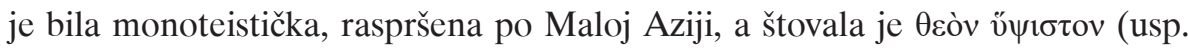
Mitchell, 1999; 2010). Pavao se je ljutio jer je morao znati da ona ne misli na Jahvu, nego na Zeusa. Luka o tom piše krajnje skraćeno, pretpostavlja da su njegovi čitatelji upoznati s tom religijom.

Međutim, zanimljiva je optužba koju su pred lokalnom upravom protiv njih digli neki rimski građani: »Ovi ljudi uznemiruju naš grad. Židovi su ${ }^{5}$ te šire običaje ${ }^{6}$ koje nama Rimljanima nije dopušteno ${ }^{7}$ ni prihvatiti ni činiti« (Dj 16,20-21). Iz konteksta nije jasno kakvi su to loši običaji koje Rimljani trebaju izbjegavati. Tužba mora biti protiv nečega što je eksplicitno zabranjeno. Naviještanje evanđelja nije bio delikt, ali je moglo biti nametanje nove religije nasuprot mos maiorum ako bi uzrokovalo nemir u gradu. No Luka ništa od toga nije specificirao. Konkretno je riječ o magiji, koja je u Rimu carskim autoritetom bila izvan zakona, ${ }^{8}$ a istjerivanje duha shvaćeno je kao magija. Vlasnici se žale jer je Pavao egzorcizmom onemogućio njihov izvor zarade. No zarada nije mogla pokrenuti bijes okupljene svjetine. Moralo je biti nešto drugo. Ključan je čin egzorcizma. Ropkinja je imala dar delfijskoga tipa proroštva, a bog nadležan za to bio je Apolon. Znamo da je August 42. pr. Kr. svoje protivnike pobijedio kod Filipa i da je za to bio posebno zahvalan bogu Apolonu, koji je zbog toga štovan u gradu.

3 Budući da tu počinje uporaba prvoga lice množine, neki zaključuju da im se je u Troadi priključio autor Luka, koji ih je pratio u svoj rodni grad Filipe.

4 Grč. $\pi v \varepsilon \tilde{v} \mu \alpha \pi v ́ \theta \omega v \alpha(\operatorname{Dj} 16,16)$. Pridjev je nastao prema delfijskoj zmiji Pitonu.

5 Možda naglašavaju da su Židovi jer im je bio poznat Klaudijev edikt o protjerivanju Židova iz Rima u to vrijeme, oko 49. godine.

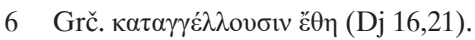

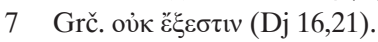

8 Car August nekoliko je puta protjerivao astrologe i mage iz Rima te spaljivao njihove spise, a to su činili također Vespazijan i Domicijan (Dickie, 2001, 137-155). 
Ako su gradska uprava i rimski građani u Pavlovu egzorcizmu vidjeli istjerivanje Apolonova duha, onda je to potencijalni sukob s carskom vlašću. ${ }^{9}$

Nakon nemiloga iskustva u Filipima Pavo i suradnici otišli su u 160 km udaljen Solun. Tri je subote raspravljao sa Židovima u sinagogi. Nastao je sukob jer su neki od njih i neki prijatelji židovske religije postali kršćani. Nezadovoljni novonastalom situacijom Židovi su htjeli Pavla i njegova suradnika Silu javno optužiti. No nisu ih našli u Jasonovoj kući gdje su odsjeli, pa su Jasona i još neke kršćane odveli pred gradsku upravu i optužili »da su pobunili cijeli svijet, ${ }^{10}$ a da Jason ugošćuje « Pavla i da svi oni »rade protiv carskih naredbi ${ }^{11}$ jer tvrde da postoji drugi kralj — Isus «12 (Dj 17,6-7). Optužba uključuje dva moguća prekršaja, koji zajedno vode u pobunu: a) ilegalne skupove (lat. collegia illicita) u Jasonovoj kući, na kojima pokušavaju pridobiti pristalice; b) osporavanje carske vlasti. I jedno i drugo protiv je carskih naredbi: Ako nisu Židovi, zabranjeno im je kao novoj religiji sastajati se tjedno. ${ }^{13}$ No drugi je dio politička denuncijacija protiv Pavla i drugih kršćana jer se aludira na nepriznavanje carske vlasti. To je zbunilo sve, pa su Jasona i ostale pustili uz jamčevinu (ili mito). Vjerojatno su uvidjeli da to nije organizirana pobuna, a nisu htjeli da slučaj ide pred rimskoga namjesnika (Hardin, 2006, 38-49).

No strah zbog tako ozbiljnih optužbi bio je jako velik. To su dobro shvatili Pavlovi prijatelji i suradnici, pa su ga na brzinu, kradomice noću odveli u grad Bereju, u podnožju Olimpa, oko 65 kilometara zapadno od Soluna, a tridesetak kilometara od mora. To je, naime, jedina neizravna optužba da Pavao ne priznaje rimskoga cara. Iako su u Solunu bili i predstavnici carske vlasti, očito je spomenuta prijava došla samo pred lokalnu upravu. Da je optužba, kako Pavao priznaje drugoga kralja a ne rimskoga cara, bila iznesena pred rimskim namjesnikom, ne bi se sve to završilo tako sretno. Da ne bi do toga došlo, prijatelji su ga na brzinu odveli iz Soluna na sigurnije mjesto.

U Bereji je bila židovska sinagoga, a Pavao je uspostavio dobar odnos sa Židovima u njoj. Mnogi su postali kršćani. Problem je nastao kada su solunski Židovi saznali da je Pavao u Bereji. Poslali su ljude koji su pobunili svjetinu protiv Pavla, tako da je morao napustiti i Bereju. Lokalni kršćani (oi ả $\delta \varepsilon \lambda \varphi o i ́)$ odveli su

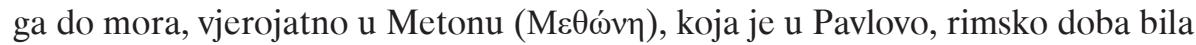
relativno prometna luka. Luka o tom piše: »Pratitelji su Pavla odveli do Atene, pa su se potom vratili i prenijeli zapovijed Sili i Timoteju da što prije dođu k njemu « (Dj 17,15). Sam Pavao o tom piše u svojoj prvoj poslanici Solunjanima: »Zato, kada više nismo mogli izdržati, pristali smo ostati u Ateni sami« (1 Sol 3,1). I sam je Pavao uvidio kako su opasne bile optužbe podignute u Solunu, pa

9 Teško je procijeniti jesu li skupovi koje je Pavao održavao u kući Lidije bili povod za njegovo uhićenje i je li Lidija, koja je bila došljakinja u Filipima, ranije pripadala monoteističkomu pokretu, što je moglo dati povoda ropkinji da Pavla i Silu oslovljava kao svećenike najvišega boga.

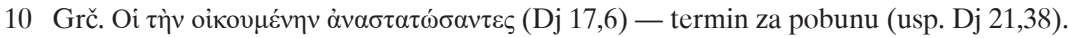

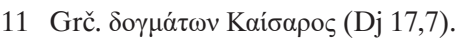

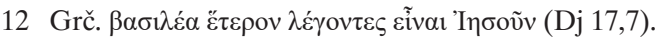

13 Taj problem je riješio Galion u Korintu i kršćane proglasio židovskom sektom. 
je pristao otići na što sigurnije mjesto. Jesu li Pavao i suradnici računali s tim da je Atena kao otvoreni grad najsigurnije utočište? Vjerojatno je već velika udaljenost od Soluna jamčila neku sigurnost.

\section{Putovanje u Atenu}

Kako, kada i s kim je Pavao putovao do Atene? Pavlovi suradnici pridružili su mu se nešto kasnije u Korintu, u koji se je Pavao uputio nakon posjeta Ateni. Podudarno o tom pišu Luka i Pavao. Neki anonimni pratitelji doslovno su ga odveli iz Metone u oko 500 kilometara udaljenu Atenu te su se vratili. Vjerojatno su činili dio skupine koja je pratila Pavla na putovanjima. Vodili su skrb oko svakodnevnih potreba, brinuli za prtljagu. Ne vjerujem da su s njim putovali kao zaštitari. Prije će biti da su pomagali oko prtljage. Malo je vjerojatno da su Pavao i pratitelji sa svom prtljagom putovali kopnenim putem. Tada ne bi imalo smisla to što Luka ističe da su lokalni kršćani uputili Pavla prema moru ${ }^{14}$ (Dj 17,14). Inače su mogli kopnenim putem nastaviti prema Ateni, ali sigurno su si uštedjeli takav naporan put jer su putovali brodom. Postojala je brodska veza od Metone do Atene.

Kako je izgledala Atena u Pavlovo vrijeme? Na vrhuncu svoje moći u klasično doba 431. pr. Kr. uže područje grada Atene imalo je 40.000 stanovnika.

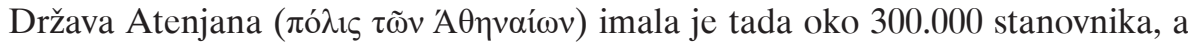
obuhvaćala je cijelu Atiku, veličine naše Istre ili države Luksemburg (Hansen, 1988, 7-13; 2006, 20-60). U rimsko doba postala je gradić s 10.000 stanovnika, sa slabo naseljenom okolicom, ali je zadržala svu svoju monumentalnu raskoš iz klasičnoga doba. Rimski su carevi još dogradili niz novih velebnih građevina. Atena je ipak bila i ostala malen i miran gradić. Kao civitas libera imala je svoju samoupravu i nije morala plaćati poreze Rimu.

Kratko rečeno, Atena je u Pavlovo doba više nalikovala na veliki muzej nego na dinamičan grad. Za starije Rimljane bila je omiljeni turistički cilj. Smatrali su je kulturnim središtem svijeta, a posebno su je cijenili i zbog velike pobožnosti. Za mlađe je bila sveučilišni grad za prestižni studij. Cezar je 47. pr. Kr. posjetio Atenu i obilno je darivao Atenjane, napose u svrhu renoviranja starih spomenika, ali car August u tome ga je daleko nadmašio. I svi kasniji rimski carevi nisu propustili priliku darivati Atenjane, a posebno se isticao Hadrijan (117.-138.), koji je bio zaljubljen u grad Atenu.

\section{Ulazak u Atenu}

Brod s Pavlom i pratiteljima mogao je pristati u veliku pirejsku luku ili malu faleronsku, koja je malo bliža gradu Ateni. Čini se da su zaista pristali u Faleronu jer je vjerojatnije da su koristili put od toga pristaništa prema gradu.

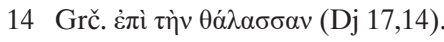


Pavao nije planirao posjetiti Atenu. Stjecajem okolnosti u Ateni je našao privremeno utočište od ozbiljne opasnosti s kojom je bio suočen u Solunu. Našao se je daleko od protivnika koji su ga mogli uplesti u ozbiljan sukob s rimskom vlašću. Budući da je u Korintu proveo godinu i pol, vjerojatno je od samoga početka planirao ići u Korint, veliki grad za ono vrijeme, oko 300.000 stanovnika, sjedište prokonzula rimske provincije Ahaje, koja je obuhvaćala južnu Grčku. ${ }^{15}$

Što se tiče Pavlova boravka u Korintu, imamo pouzdano vrijeme. Tamošnji su Židovi došli u sukob s njim, pa su ga tužili prokonzulu Galionu, starijemu bratu filozofa Seneke. Prokonzul je odbio optužbe tvrdeći kako je riječ o internim židovskim razlikama. Galion je bio prokonzul od 51. do 52. godine. Pavao je došao u Korint iz 80 kilometara udaljene Atene vjerojatno u ljeto 51. godine. Luka kaže da su Židovi tužili Pavla dok je Galion bio prokonzul Ahaje (Dj 18,12). ${ }^{16}$ Moguce je da Luka time hoće reći da se Pavlov i Galionov boravak u Korintu vremenski ne podudaraju. Sasvim je u pravu jer je mandat prokonzula trajao samo godinu dana, a Pavao je bio pola godine duže u Korintu. Židovi su ga tužili dok je Galion bio na dužnosti prokonzula. ${ }^{17}$ U skladu s tim možemo reći da je Pavao boravio u Ateni u ljeto 51. godine.

Pavao je vjerojatno stigao u faleronsku luku. Sa svojom su prtljagom trebali za 2-3 sata stići do grada. Sigurno su koristili usluge nekih domaćih prijevoznika jer ljeti su u Atenu, kao najveću kulturnu atrakciju onoga doba, dolazile tisuće turista, ne samo iz Rima, nego i drugih dijelova Rimskoga Carstva. Doći u Atenu, vidjeti monumentalne spomenike, čuti uživo kojega filozofa — to je bio turistički san mnogih Rimljana. Lokalni prijevoz od luke do grada sigurno je dobro funkcionirao. Za Pavla, kao iskusnoga misionara, nije bio problem stići pješice za dva sata od pristaništa do podnožja Akropole. Vjerojatno su ga do samoga grada i prvoga smještaja pratili prijatelji. Zbog prtljage unajmili su barem skromniju zapregu s magarcem.

Već od samoga pristaništa pratili su ih sakralni objekti. Najbolju predodžbu o tom kako je to Pavao mogao doživjeti možemo steći ako pročitamo sami početak Pauzanijeva Opisa Grčke. Put od atenskih luka do grada, koji je on prošao sto godina poslije Pavla, detaljno opisuje navodeći mnoštvo kipova, hramova, svetišta i žrtvenika. Kada danas u muzejima gledamo ukradene dijelove tih spomenika,

15 To je bio novi Korint, rimska kolonija, kozmopolitski grad naseljen veteranima i oslobođenim robovima, velika luka i poslovni grad šarolike ponude, na ulici se govorilo grčki i latinski, a u gradu je bila i sinagoga (Vidović 88-89).

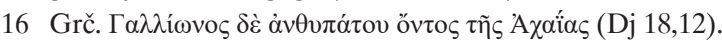

17 Luka ističe da je Pavao »svake subote raspravljao u sinagogi«(Dj 18,4). To je bio privilegij koji je Židovima omogućio car August jer ostale su se religijske skupine (collegia) mogle sastajati samo jednom mjesečno (Robinson, 1995, 80). Nastao je sukob s lokalnim Židovima, pa je Pavao preselio kod Ticija Justa, koji je bio prijatelj židovske religije, a kuću je imao do sinagoge. U toj su se kući sastajali prvi kršćani, vjerojatno jednom tjedno. Židovi su kod Galiona optužili Pavla da

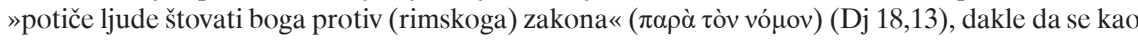
sljedbenici nežidovske religije ne sastaju samo jednom mjesečno nego češće (usp. Winter, 2012, 70). Galion je odbio tužbu jer optuženi tjednim religijskim susretima nisu kršili zakon — time je korintske kršćane de iure proglasio židovskom sektom. 
djeluju blijedo, samo sivi kamen. U klasično i Pavlovo doba svi su ti spomenici, posebice statue, bili šareno obojeni, a prevladavala je crvena i plava boja. U tih sto godina Atena se je promijenila samo malo oko glavnoga trga. Pauzanijeva šetnja do grada Atene može nam zbog primarnih religijsko-kultnih opisa dočarati kako je Pavao mogao doživjeti taj hod i dolazak u grad.

Vjerojatno su Pavao i pratitelji koristili put od Falerona prema gradu. Na tom su putu mogli vidjeti nešto što Pavao ističe u svojem govoru pred Areopagom. Pauzanije kaže: »Još je kod Falerona bila jedna luka [...] a kod nje [...] su se nalazili žrtvenici takozvanih nepoznatih bogova «. ${ }^{18}$ Jasno je da je bilo više takvih žrtvenika. No nije jasno što je stajalo na tim žrtvenicima: žrtvenik nepoznatoga boga ili žrtvenik nepoznatih bogova. Ne znamo što je Pavao točno vidio u Ateni i njezinoj okolici. Pauzanije kaže da je u Olimpiji pokraj Zeusova žrtvenika vidio još neke, ali i jedan koji je bio posvećen nepoznatim bogovima. ${ }^{19}$ Je li Pavao negdje u Ateni i okolici vidio natpis nepoznatomu bogu ili nepoznatim bogovima, nemoguće je utvrditi. Za svoju je apologiju monoteizma trebao i uporabio jedninu. Pauzanijev izraz zapravo znači “žrtvenici neimenovanih bogova”. Da bi bili poznati netko ih mora predstaviti i navesti ime, a da bi bili priznati i prihvaćeni u Ateni, to još dodatno mora odobriti Areopag. U antici nije poznat slučaj da je namjerno štovano neko nepoznato božanstvo. Za politeističku je religiju jako važno imenovati bogove jer samo tako postaju bliski i lokalna ih tradicija može usvojiti.

Iako je Pavla kao monoteista krajnje ljutila ta nepregledna raskoš mnogobožačkoga idolopoklonstva, ipak detalj sa žrtvenicima posvećenim neimenovanim bogovima nije mu promaknuo - dobro ga je upamtio. Kako je dolazak i ulazak u grad izgledao, možemo si zamisliti. Cijelim su ih putem pratili bezbrojni sakralni objekti, što nam najbolje potvrđuje Pauzanije svojim šetnjama po gradu i okolici.

Lukino izvješće o Pavlovu boravku u Ateni možemo podijeliti u tri cjeline. Prvo slijedi kratak opis njegova boravka (Dj 17,16-21), potom govor pred Areopagom (Dj 17,22-31), a na koncu se opisuje učinak toga govora (Dj 17,32-34). U ovom radu obrađujem samo prvi dio. Odgovarajući tekst navodim u svojem prijevodu i komentiram.

\section{Boravak u Ateni}

\subsection{Pogođenost bezbrojnim idolima}

»Dok je Pavao u Ateni čekao svoje suradnike, u sebi je svojim duhom bio ogorčen jer je promatrao kako je grad prepun idola « $(\mathrm{Dj} 17,16) .{ }^{20}$

Pavao je poznavao mnoge velike gradove onoga vremena. Nije mogao ne zamijetiti da Atena, kako arhitekturom tako i sakralnim objektima, daleko nad-

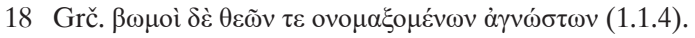

19 Grč. $\alpha \gamma v \omega ́ \sigma \tau \omega \nu \theta \varepsilon \tilde{\omega} v \beta \omega \mu \mathrm{s}$ (5.14.8).

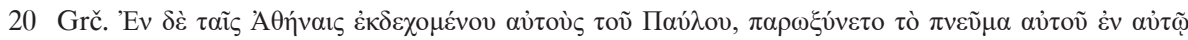

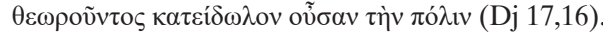


mašuje sve gradove koje je posjetio. Ne znamo kako je to doživio, no Luka nam spominje njegovu pogođenost bezbrojnim idolima, koji su ga sablažnjavali i s obzirom na njegovo židovsko podrijetlo, ali jednako tako s obzirom na kršćansku egzistenciju. Prikazao je njegov doživljaj Atene iz perspektive kršćanskoga misionara. Možda je Pavao kasnije, dok je drugima pričao o svojem boravku u Ateni, isticao upravo taj aspekt. Možda je netko to i zapisao. No, u kratkom opisu Luka Pavlov duševni nemir opisuje primjereno sredini u kojoj se je našao dapače prikazuje ga namjerno kao suzdržanoga stoičkoga filozofa. Ogorčenost ( $\pi \alpha \rho \omega \xi \tilde{v} v \varepsilon \mathrm{o})$ neprihvatljivim idolima u najpoznatijem gradu kulture i poganske religioznosti razljutila ga je duboko u duši, ali — kako Luka to lijepo opisuje -

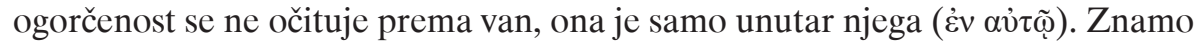
kako je inače bio temperamentan, kako je vikao na apostola Petra zbog prevelikoga obzira prema judeokršćanima (Gal 2,11-14). U Ateni Pavao je posve miran i suzdržan, ravnopravan stoičkim filozofima.

Koliko je Luka znao o Pavlovu poznavanju ondašnje filozofije i je li sam Pavao usvojio stoički pristup kontrole osjećaja, teško je znati. U ranoj dobio stekao je opće obrazovanje onoga vremena u svojem rodnom gradu Tarzu, ali je vrlo rano farizejsko obrazovanje nastavio u Jeruzalemu. Također je naučio zanat pravljenja šatora ( $\sigma \kappa \eta v o \pi$ oı́ $\varsigma$ ), a to je znanje neko vrijeme koristio u Korintu. Vjerojatno je to bio obiteljski obrt, a moguće je da je njegov djed ili otac stekao rimsko građanstvo jer je rimsku vojsku opskrbljivao šatorima. Ima li Pavlovo rimsko građanstvo neke veze $\mathrm{s}$ činjenicom da je najčešće misionario u rimskim kolonijama? Ti su gradovi bili, pored administrativne uporabe latinskoga jezika, uglavnom helenizirani i otvoreniji nego neka tradicionalna maloazijska i bliskoistočna sredina. Osim toga, u njima su se češće nalazile židovske zajednice. Pavlov rodni grad Tarz bio je prema Strabonu poznat po visokom obrazovanju, premda malo pretjeruje kada kaže: »Stanovnici Tarza tako su se posvetili filozofiji i ostalim područjima obrazovanja da su nadmašili Atenu, Aleksandriju i druge gradove« (14.5.13). Atenodor (oko 74. pr. Kr. — 7. godine), rođen u Kananu pokraj Tarza, Posidonijev učenik, Ciceronov prijatelj, bio je osobni filozof cara Augusta. Naučio je cara da, kada je ljut, prvo prođe abecedu kao popularno stoičko sredstvo smirivanja. Pavao je mogao od njega preuzeti i razraditi pojam

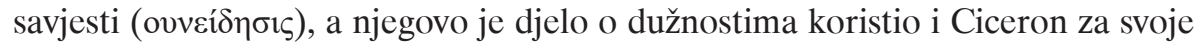
istoimeno djelo.

\subsection{Pavao naviješta u sinagogi i na agori}

»Subotom je u sinagogi raspravljao sa Židovima i pobožnim prijateljima židovske vjere, a svaki je dan na gradskom trgu vodio raspravu s onima koje bi ondje sreo« $(\mathrm{Dj} 17,17){ }^{21}$

I u Ateni Pavao je slijedio svoj misionarski obrazac. U svakom se je gradu prvo obratio Židovima u sinagogi, tj. Židovima koji su živjeli u dijaspori i u pra-

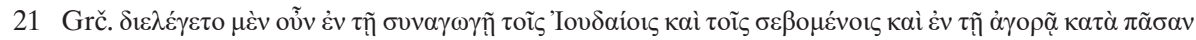

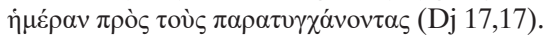


vilu su bili helenizirani. Zašto je to činio? Ima više odgovora na to pitanje. Prirodno je da je u stranom svijetu prvo tražio kontakt sa sunarodnjacima. Nema sumnje da se je u svakom gradu obraćao i drugim građanima. Mislim da je Pavlovo polaženje od Židova također povezano s teškoćama koje je imao s nežidovima kada im je pokušavao približiti Evanđelje. Židove i kršćane veže monoteizam, a uloga Isusa Krista kao mesije zapravo se najlakše može objasniti starozavjetnim učenjima. Kršćanstvo je nesumnjivo počelo kao židovska sekta i postupno se je osamostalilo — za što je najzaslužniji Pavao. No helenističke religije vrvjele su različitim božanstvima, pa je bilo jako teško pripadnike tih religija uvjeriti u temelje kršćanske vjere.

Za Židove je Pavao imao čvrst obrazac kako im približiti svoja vjerovanja. Nije trebao koristiti neku posebnu apologiju monoteizma jer se je obraćao monoteistima. Prije nego što je govorio o Isusu i uskrsnuću, navodio je starozavjetna proročanstva o mesiji. Židovima je mogao reći da govori o njihovu bogu. Tipičan je takav govor — i jedini koji je potpun — onaj koji je Pavao održao u sinagogi u pizidijskoj Antiohiji, maloazijskoj rimskoj koloniji (Dj 13,16-41). Slično su strukturirani Petrovi govori, a takav je i Stjepanov govor. Dakle kršćanska misija imala je najbolje uvjete prijemčivosti u židovskim zajednicama. Druga skupina onih kod kojih je kršćanska misija od samih početaka imala odjeka bili su $\sigma \varepsilon \beta o ́ \mu \varepsilon v o 1$, kako ih zove Luka, tj. prijatelji židovske religije. Riječ je o nežidovima koji su simpatizirali s monoteizmom židovske religije. Dolazili su često subotom u sinagogu, družili se sa Židovima, ali nisu u potpunosti prihvaćali Mojsijev zakon.

No bilo je puno teže pristupiti helenističkim politeistima. U Djelima apostolskim nemamo puno takvih primjera. Prvo izravno obraćanje nežidovima, odnosno prvu, vrlo kratku apologiju monoteizma nalazimo u maloazijskoj Listri, također rimskoj koloniji (Dj 14,15-17). Drugu, potpuniju apologiju imamo u Ateni. Taj je atenski govor najranija sačuvana apologija kršćanskoga monoteizma. Za Pavla je to bio veliki izazov, a Luka je vrlo ozbiljno shvatio važnost i zahtjevnost sredine u kojoj Pavao iznio svoju apologiju. Važan je još jedan detalj. Vrlo je često poticaj da se povjeruje dalo nadnaravno čudo, primjerice iscjeljenje. Slično se je dogodilo u Listri, ali čudo je prethodilo bez iznošenja evanđelja, pa su lokalni pogani pogrešno shvatili kontekst te su Pavla i Barnabu proglasili bogovima. Pavlova apologija imala je svrhu popraviti taj nesporazum. Za razliku od toga svega, u Ateni je djelovanje u sinagogi bilo u pozadini, a u prvi je plan stavljen nastup pred poganima. Nije koristio nadnaravno čudo i nije se pozivao na starozavjetni kontekst, nego samo na filozofsko-teološke argumente, koji su prisutne trebali uvjeriti na racionalan način. Tek na koncu govora, kada prelazi na kršćansku apologiju, dolazi do nesporazuma s poganskom publikom.

U Ateni je Pavao u sinagogi raspravljao ${ }^{22}$ samo subotom, kako sam dodao u prijevodu. U gradu je prema tomu boravio najmanje nekoliko tjedana. Sinagoga je bila u lučkom dijelu grada, a kontakti između Atene i Jeruzalema postojali su već nekoliko stotina godina (Bilde, 1993; Schäfer, 1995; Gruen, 2002; Unnik, 1993). 


\subsubsection{Agora u Pavlovo vrijeme}

Luka ističe kako je Pavao svaki dan ${ }^{23}$ raspravljao s prolaznicima na agori. Čini se kao da je više komunicirao s Atenjanima i turistima nego sa Židovima. Ne znamo gdje je boravio. Pratitelji ga nisu samo ostavili u gradu, nego su ga sigurno odveli nekoj osobi od povjerenja koja je mogla biti bliska kršćanima, najvjerojatnije židovskoga podrijetla. Na taj je način mogao biti u stalnom kontaktu sa Židovima i subotom ići u sinagogu.

Kakvu je agoru Pavao mogao vidjeti u to vrijeme? Na periferiji je bilo lakše sakralno razlikovati od nesakralnoga, no na glavnom trgu teško je bilo lučiti čisto sakralne objekte od javnih zgrada. To je upravo tipično za atensko shvaćanje religije - nema jasnoga razgraničenja što je religija i javni kult, a što očitovanje političke volje atenskoga naroda. Agora koju je vidio Pavao već se je dosta razlikovala od one kojom se je kretao Sokrat i gnjavio svoje sugrađane. Prostorno je bila dva puta veća od Jelačić placa u Zagrebu (koji je oko 1,2 hektara), oblika nepravilnoga trapeza, na jugu prema Akropoli omeđena brežuljkom Areopagom. Bila je kao zajednički javni prostor formalno-pravno odvojena od ostatka grada

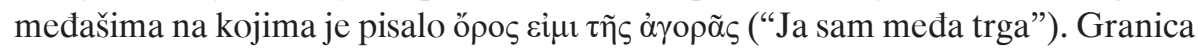
je značila da se nije smjelo graditi unutar trga, a neki su dobili zabranu ući u taj javni prostor. U klasično doba, dakle u 5. i 4. stoljeću pr. Kr., središnji je prostor bio otvoren. Gotovo svaki tjedan na tom se je prostoru okupljalo najmanje 6.000 ljudi (kvorum da mogu donositi odluke), a svakodnevno su na trgu ili u obližnjim zgradama bile aktivne i ostale institucije atenske države. Grad i okolica bili su puno naseljeniji nego u Pavlovo vrijeme, pa je sve vrvjelo različitim aktivnostima: već spomenutom političkom, u što su spadali i sudovi, trgovalo se je i raspravljalo, prodavana je roba i misli.

Trg je već u klasično doba dijelom bio omeđen nekim monumentalnim građevinama. Spomenut ću samo neke. Na sjeverozapadnom dijelu nalazila se je kraljevska stoa ( $\sigma \tau$ oò $\beta \alpha \sigma i ́ \lambda \varepsilon เ \varsigma \varsigma)$, pravokutnoga oblika (18 m · 7,5 m), s 8 dorskih stupova, otvorena prema trgu. Bila je sjedište kralja arhonta ( $\alpha \rho \chi \omega v \beta \alpha \sigma i \lambda \varepsilon v ́ \varsigma)$. Nema nikakve veze s monarhijom, nego je stari atenski naziv kultne i religijske nadležnosti. Kralj arhont određivan je ždrijebom među arhontima na godinu dana, a organizirao je religijske svečanosti, dodjeljivao nagrade za tragediju i komediju i dr. Budući da je bio optužen za religijski delikt, tu se je pred kraljem arhontom morao pravdati Sokrat prije postupka. Nešto se je slično dogodilo i Pavlu na tom mjestu. Malo dalje prema istoku, na sjevernom rubu, nalazio se je šareni trijem na stupovima ( $\sigma \tau$ oò $\pi$ oıkı $\lambda$ )́), veličine $12,5 \mathrm{~m} \cdot 36 \mathrm{~m}$. Već je u klasično doba bio neka vrsta muzeja sa slikama i skulpturama. Bio je omiljeno sastajalište za Atenjane, dobro ih je štitio od jakoga sunca i kiše. Tu je Zenon započeo svoj filozofski rad, pa odatle i ime za stoičku školu. Na kraljevski trijem nastavljala se je prema jugu stoa posvećena Zeusu $(11 \mathrm{~m} \cdot 45 \mathrm{~m})$, a sasvim na jugu bila je još jedna stoa, više puta dograđivana u helenističko doba, pa je s vremenom postala 
najveća $(17,5 \mathrm{~m} \cdot 147 \mathrm{~m})$. Osim tih javnih građevina možemo istaknuti jedan važan sakralni objekt, koji je Pavao mogao vidjeti dok se je šetao trgom ili kada je držao svoj govor. Od kraljevskoga trijema na tridesetak metara udaljenosti mogao je u slobodnom prostoru vidjeti žrtvenik posvećen 12 najvažnijih bogova.

Sve te građevine iz klasičnoga doba ostale su netaknute i Pavao ih je mogao vidjeti. Što se je promijenilo u postklasično vrijeme, dakle između Sokrata i Pavla? (usp. Benavidas, 2019; Burden, 1999; Parigi, 2013). U helenističko doba trg je zatvoren sa strane, a za vrijeme carskoga Rima slobodni prostor na agori postupno je punjen novim građevinama. Dakle, trg je prvo dodatno zatvoren $s$ istoka i juga monumentalnim trijemima na stupovima. $\mathrm{Na}$ istoku se je nalazio monumentalan trijem $(20 \mathrm{~m} \cdot 115 \mathrm{~m})$ na dva kata. Darovao ga je atenskomu narodu kralj Pergama Atal II. Filadelf. Služio je kao velika robna kuća. Rimljani su dali velike donacije za obnovu i daljnju izgradnju grada. Car August izgradio je sjeverno od Akropole i istočno od staroga trga takozvanu rimsku agoru, veličine Jelačić placa (98 m · $111 \mathrm{~m})$, obrubljenu trijemima na stupovima. Rimska je agora preuzela mnoštvo trgovina i poslovnih prostora sa stare agore. Na taj je način stara agora postala veliki otvoreni muzej, koji je još nekim rimskim dodatcima postao izrazito sakralni prostor.

U rimsko doba velike je promjene doživio atenski glavni trg. Prekinuta je tradicija otvorenoga prostora, koji je već od samoga početka Augustove vladavine bio arhitektonski zatvoren. Neuređen put koji je vodio prema Akropoli i koji je stoljećima korišten, a išao je preko agore od kraljevskoga trijema, lijevo od žrtvenika za 12 olimpskih bogova do jugoistočnoga prilaza trgu, popločen je i obrubljen. Spomenut ću još dva velika arhitektonska projekta. Ispred skoro 150 metara dugoga trijema na jugu izgrađen je takozvani Agripin Odeon. Augustov zet dao ga je izgraditi oko 15. pr. Kr. kao glazbenu dvoranu, veličine $52 \mathrm{~m} \cdot 43$ m, s krovom raspona 25 metara (koji se je stotinu godina poslije Pavlova posjeta Ateni urušio). Dvorana je imala korintske stupove i mogla je primiti oko tisuću posjetitelja. Druga nešto manja zgrada postavljena je posred agore, tridesetak metara južnije od žrtvenika dvanaestorici bogova, također u Augustovo doba, inicijativom istoga zeta. To je bio hram, veličine $16 \mathrm{~m} \cdot 35 \mathrm{~m}$, sa šest puta po trinaest dorskih stupova, posvećen bogu Aresu. Priča s tim hramom neobična je. Potječe iz 5. stoljeća pr. Kr. i nalazio se je u ruralnom dijelu Atike, koji je u to vrijeme bio slabo naseljen. Rastavljen je i prenesen na atensku agoru, koju godinu poslije Agripina Odeona. Hram je izvorno bio posvećen božici Ateni, a rimski ga je general dao obojiti u plavo i posvetiti bogu rata, omiljenomu bogu cara Augusta.

Ne znamo kako je Pavao doživio taj muzejski prostor na agori. Budući da je teško bilo lučiti sakralno i profano, vjerojatno je to sve pojačavalo njegovo nezadovoljstvo mnogobožačkim duhom grada. Svoj je govor držao pored kraljevskoga trijema, iza njega bila je šarena stoa, ispred njega veliki žrtvenik, a u pozadini Aresov hram. Sigurno je obišao cijeli trg i Akropolu — grad nikada dotada nije izgledao raskošnije, bio je uređeniji i djelovao je puno monumentalnije nego u vrijeme Sokrata. Možda je samo u Hadrijanovo vrijeme Atena djelovala 
još bogatije. Pavlov doživljaj Atene možemo usporediti s Lutherovim posjetom renesansnomu Rimu 1511. godine. Iako su pred sobom imali dva umjetnošću najfascinantnija grada u povijesti, obojica su — inače poznati kao svadljivi i temperamentni — bili smireno ogorčeni, svatko na svoj način.

\subsubsection{Tko su Pavlovi sugovornici i slušatelji}

»No neki epikurejski i stoički filozofi upadali su mu u riječ. Jedni su govorili: Što bi ovaj brbljavac htio reći? A neki su drugi rekli: Čini se da je navjestitelj stranih božanstava jer je naviještao Isusa i uskrsnuće « $(\mathrm{Dj} 17,18){ }^{24}$

Pavao se je svakodnevno također obraćao ljudima na agori i s njima raspravljao - teme su sigurno bile Isus i uskrsnuće. Nije isključeno da su neki površno zaključili da se Pavao poziva na dva njima nepoznata božanstva, Isusa i Anasta-

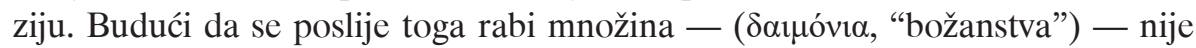
nemoguć taj nesporazum.

Je li vjerojatno da je susreo neke epikurejske i stoičke filozofe? Obje su škole bile djelatne u to vrijeme te su nesumnjivo imale zastupnike u Ateni. Spominjanje te dvije škole mogla bi biti Lukina konstrukcija iz perspektive njegova doba ${ }^{25}$ — te su dvije škole tada bile u javnosti najviše eksponirane, i malo bolje informirani stanovnici carstva znali su za njih. Platonova i Aristotelova škola nisu u to vrijeme bile jako poznate u javnosti. Ako je Pavao, prema svojemu kasnijemu iskazu, zaista stupio u raspravu s epikurejcima i stoicima, onda je najvjerojatnije da je na javnom atenskom trgu mogao doći u bliski susret upravo s njima. Akademici i peripatetici nisu bili tako otvoreni za ulične rasprave. Mislim da je riječ o građanima Atene koji su bili svjesni svoje filozofske tradicije, ponešto informirani, pa su se samouvjereno upustili u raspravu s Pavlom, pri čemu su se pozivali na dvije spomenute filozofske škole. Slušali su Pavla, dobacivali mu svoj komentar ili ga prekidali pitanjima. Budući da se je Pavao pojavljivao svaki dan, sigurno su ga uočili neki Atenjani koji su više puta raspravljali s njim. Luka je od samoga početka uočio dvije skupine slušača: jedni su dobronamjerni, drugi su nepovjerljivi. Slušateljstvo se uvijek može podijeliti tako neprecizno.

Jedni su ga podrugljivo nazivali brbljavcem, ${ }^{26}$ a drugi su ozbiljnije analizirali njegovo izlaganje. Oni koji su pozornije pratili Pavlove argumente shvatili su da su ključne riječi Isus i uskrsnuće, pa su imali dojam da naviješta neka strana bo-

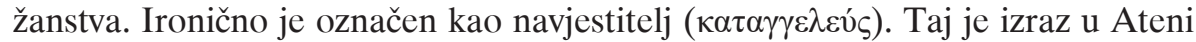
rabljen za člana Areopaga koji je trebao izvijestiti ostale članove o prihvatljivosti

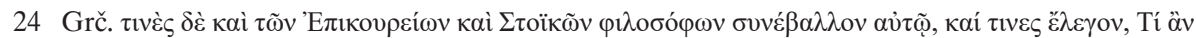

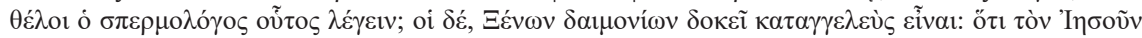

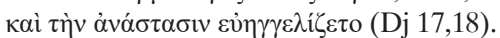

25 Luka voli istaknuti podjele. Tako u Dj 23,6-10 Pavao takoreći zlorabi židovsku podjelu na farizeje i saduceje.

26 Uporabljena je rijetka riječ $\sigma \pi \varepsilon \rho \mu$ ¡óóos, koja doslovno označava nekoga tko skuplja sjemenke, napose čavku koja se hrani sjemenkama, ali i koja je brbljava i voli krasti — metaforički za čovjeka koji brbljavo pametuje nekim ukradenim mislima. Mogli su aludirati na to da Pavao skuplja i krade njihovu mudrost. 
ili neprihvatljivosti nekoga novoga kulta. Bio je svećenik carskoga kulta, nalazio se je na listi arhonta, a također je čuvao pečat grada Atene (Geagan, 1967, 24-40). Ako uvjeri ostale članove vijeća, novo je božanstvo uvršteno u Partenon, te mu je mogao biti izgrađen žrtvenik ili hram.

Sadržaj koji Pavao naviješta su strana božanstva ( $\xi \xi \dot{\varepsilon} \alpha \alpha \delta \alpha \mu o ́ v ı \alpha)$. Podsjeća na

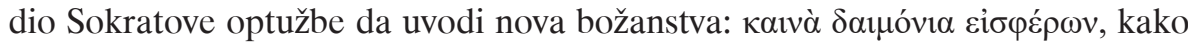
kaže Ksenofan na početku svojih sjećanja na Sokrata (također Platon, Apol. 24b). Aludira li Luka namjerno na Sokratovu optužbu? Može li to potvrditi jedna

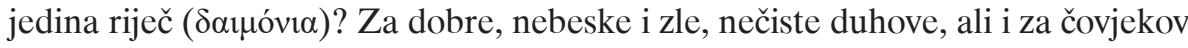
nutarnji duh (često kod Pavla u tom smislu), rabi se u Novom zavjetu $\pi v \varepsilon v \tilde{\mu} \alpha$, česta riječ. Termin $\delta \alpha \mu$ óvıov nije tako čest, znači uglavnom isto što i $\pi v \varepsilon \tilde{v} \mu \alpha$. No samo na jednom mjestu u Novom zavjetu imamo isto značenje te riječi kao u Sokratovoj optužbi, a to je ovo naše mjesto. Prema tomu, samo je jedna riječ, ali Luka ju je nedvojbeno mogao namjerno uporabiti kao aluziju na Sokrata.

\subsubsection{Areopag u Pavlovo doba}

»Potom su ga uhvatili za ruku i odveli pred Areopag. Pritom su mu kazali: Možemo li saznati kakvo je to novo učenje o kojem ti govoriš? « $(\operatorname{Dj} 17,19) .{ }^{27}$ »Jer neke neobične priče unosiš u naše uši. Zato želimo saznati što bi to trebalo biti« (Dj 17,20). ${ }^{28}$ »Inače svi Atenjani i doseljeni stranci ne običavaju ni za što drugo koristiti svoje vrijeme kao za to da nekomu ispričaju ili da od nekoga čuju neku najnoviju vijest « $(\mathrm{Dj} 17,21){ }^{29}$

Doslovno su ga zgrabili i odveli pred Areopag. Nakon višednevnoga pojavljivanja Pavao je sigurno zapao za oko mnogim Atenjanima. Neki su bili zbunjeni ili uznemireni njegovom upornošću i neobičnim tvrdnjama koje je iznosio. Oni koji su ga poveli, kao da su htjeli opravdati svoj postupak, ponavljali su kako žele

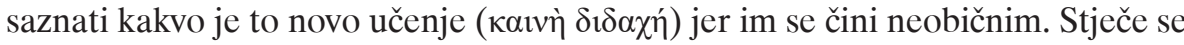
dojam kao da ga pozivaju da u miru objasni svoje stavove. Nema puno smisla da su ga odveli filozofi s obrazloženjem da žele više saznati i bolje shvatiti njegovo učenje. To su mogli postići bez drastičnoga hvatanja za ruku i odvođenja na neko drugo mjesto jednostavnim podpitanjima i sudjelovanjem u raspravi. Malo je vjerojatno da bi filozofi Pavla tužili za religijski delikt. Mogli su ga odvesti neki drugi građani koji su sumnjali u njegove religijske stavove, pa su htjeli više saznati pred nadležnom ustanovom kakvo je to neobično učenje ( $\xi \varepsilon v i ́ \zeta o v \tau \alpha)$ i je li u sukobu s njihovom tradicijom. Možda su reagirali i lokalni policajci koji su više puta vidjeli stranca Pavla kako raspravlja s prolaznicima. Atena je ipak bila malen grad. Za policiju je bio u tadašnjoj Ateni nadležan Areopag. No Pavao je mogao zapasti za oko i nekomu članu Areopaga. Mogao je već ranije impresionirati Dionizija.

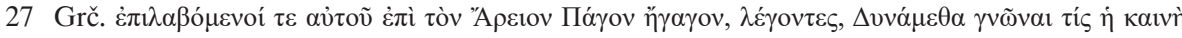

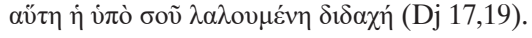

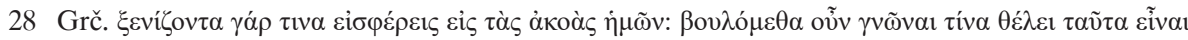
(Dj 17,20).

29 Grč. A A

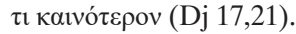


Zanimljiv je Lukin dodatni komentar u Dj 17,21 kojim karakterizira rođene i

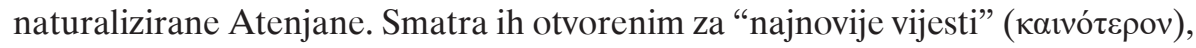
kako sam ja preveo. To je takoreći mentalitet grada, otvorenost i znatiželja koja zarazno djeluje i na došljake. Je li to interes za tračeve ili za nove spoznaje? I jedno i drugo bilo je tipično za atenske stanovnike. U tom se komentaru također osjeća blaga ironija jer se može shvatiti da su zapravo Atenjani pravi $\sigma \pi \varepsilon \rho \mu \mathrm{\nu}$ ó a ne Pavao. Osim toga, tim se dodatkom može dijelom objasniti dovođenje Pavla na ispitivanje pred Areopag, jer oni koji su inicirali dovođenje žele više saznati o novoj religiji. Kada je Pavao počeo svoj govor, a to je bilo na javnom mjestu, atenski su se građani počeli znatiželjno skupljati i slušati govor. Zato taj Lukin komentar o mentalitetu stanovnika zapravo anticipira ono što se je događalo za vrijeme govora. Atena je uvijek bila poznata po svojim samouvjerenim i znatiželjnim građanima, a Pavao je to sigurno zamijetio.

Postavlja se pitanje misli li se u Lukinu tekstu Areopag kao brežuljak ili kao institucija pred kojom je trebao opravdati svoja religijska shvaćanja. Neki Areopag tumače lokalno. Kako je na trgu vladala gužva, odveli su ga na obližnji brežuljak kako bi ga mogli u miru slušati. I danas je to u Ateni mirnije mjesto s kojega se pruža lijep pogled. No to nema puno smisla jer, kako sam već opisao, agora je bila dovoljno velika, a u rimsko je doba bilo ipak mirnije nego u klasično. Lako se je mogao naći mirniji kutak. To također ne objašnjava opis kako su ga zgrabili i takoreći odvukli pred Areopag. No potpuno je pogrešno da su ga odveli na brdo da bi mu sudili. To nikada nije bio dio procedure. Pavao je sigurno dospio pred institucionalni Areopag. Kao optuženik? Ne, jer nikakva formalna tužba nije bila podignuta. No morao se je pravdati kao sumnjivac. Da je u tom prvom sučeljavanju otkriveno išta neprihvatljivo, sigurno bi bila dignuta formalna optužba. U Pavlovo vrijeme, dakle u rimsko doba, Areopag je bio — za razliku od klasičnoga doba — najvažnija i najmoćnija politička institucija u Ateni. Kako je došlo do te promjene? Kako se je atenska demokracija pretvorila u aristokraciju?

Za vladavine makedonske dinastije Antigonida (277.-168. pr. Kr.) Atena je uživala relativnu autonomiju, ali je došlo do ključnih promjena političkih institucija. Ukinut je izbor ždrijebom za političke dužnosti, počelo se je opet birati preferencijama, načelo koje je još Aristotel označio kao aristokratsko, a često je ključno bilo i imenovanje od strane moćnika. Također je omogućeno da se izabrana osoba bira neograničen broj puta - atenski su demokrati smatrali izbor ždrijebom najpravednijim jer su pritom svi jednaki, a izbor se više nije mogao ponoviti jer su i drugi trebali doći na red da vladaju. Tom novom praksom dvije

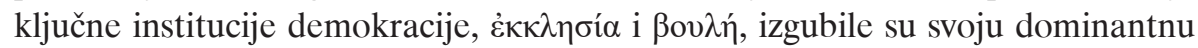
funkciju. Također je ukinut jedan drugi temelj atenske demokracije, a to je plaćen politički rad. Primjerice, za sudjelovanje u radu skupštine, a bio je potreban kvorum od 6.000 sudionika, plaćano je iz državnoga budžeta — dovoljno za dnevnu hranu jedne manje obitelji. Agora nije više, najmanje jednom tjedno, vrvjela od građana pridošlih na skupštinu sa svih strana Atike. Pod novim uvjetima, a i grad se je smanjio i puno osiromašio u odnosu na Periklovo i Sokratovo doba, 
mogli su se kandidirati samo bolje stojeći građani, pa je Atena postala aristokratski režim, a stara aristokratska institucija Areopag stekla je najveću moć u gradu.

Areopag je u Pavlovo vrijeme predstavljao izvršnu vlast rimske Atene — koja je u gradu imala više ovlasti nego što je rimski senat imao u Rimu — ali i vrhovni sud, određivao je sve bitne aspekte zajedničkoga života, od mira i reda u gradu, dakle policijska nadležnost, do određivanja detalja u religijskom životu, primjerice tijek kultnih svečanosti, prihvaćanje stranih kultova, provođenje carskoga kulta, ali isto tako je brinuo za kulturu i obrazovanje. Svake je godine birano vijeće Areopaga, ukupno devet članova, a dodijeljene su im određene dužnosti. Reizbor je u rimsko doba bio moguć. Najprestižniju je dužnost imao ő $\chi \omega \omega v$ $\dot{\varepsilon} \pi \omega ́ v v \mu$ os. Druga po prestižnosti bila je dužnost koju je obnašao ó $\rho \omega v \beta \alpha \sigma i \lambda \varepsilon v ́ \varsigma$, kralj arhont, nadležan za religijska pitanja i krvne delikte. Pred njega je sigurno doveden Pavao u njegov ured, koji se je nalazio u kraljevskom trijemu. Ostali su arhonti imali različite dužnosti, a većina je imala sudske ovlasti.

Kako je tekao službeni dio Pavlova nastupa pred Areopagom? Pojedinosti ne znamo. Nisu nam poznati slučajevi iz toga doba, pa se nameće usporedba sa Sokratom. Ako je nešto bilo sumnjivo, prvo je slijedila predistraga ( $\alpha$ óx

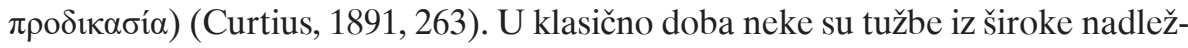
nosti Areopaga odmah proslijeđene u redovitu sudsku proceduru ( $\left.\eta_{\lambda} \iota \alpha i \alpha\right)$, primjerice u slučaju Sokrata. No u njegovu slučaju ipak je to bio politički postupak. Pavao nije bio u sličnoj situaciji — njegov je slučaj bio bezazlen. Međutim, u 5. i

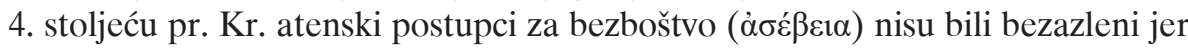
su mogli završiti smrtnom kaznom.

Poslije klasičnoga doba nemamo nikakve vijesti da je u Ateni netko optužen i kažnjen zbog bezboštva. Pavlov je slučaj jedini koji nam je poznat, ali areopaško vijeće zaključilo je da u njegovim stavovima nema ništa prijeporno, pa uopće nije došlo do optužbe. U tih nekoliko stoljeća atenska je religija postala otvorenija za nove kultove. Da je vijeće otkrilo nešto prijeporno, ne znamo kako bi postupilo možda samo protjerivanjem optuženoga. Ako bi se prijepor odnosio na osporavanje carskoga kulta, a to je opasan delikt, slučaj bi proslijedili prokonzulu u Korintu.

\section{Zaključak}

Prema Lukinu izvješću, Pavlovo drugo misijsko putovanje Božjom je providnošću usmjereno na Makedoniju. Prema ostalim izvorima znamo da je ta misija bila vrlo uspješna. No, protivnici su ga svojim optužbama doveli u potencijalni sukob s rimskom vlašću. U Filipima su ga rimski građani optužili za bavljenje magijom, u Solunu Židovi za ilegalne skupove i nepriznavanje cara, pa je otišao u treći makedonski grad Bereju. Ni ondje nije bio siguran, pa je morao prekinuti makedonsku misiju i otići što dalje. Prvotni je plan vjerojatno bio nastaviti misiju u Korintu. Iz nekoga razloga nije odmah otišao u Korint, nego je nekoliko tjedana sam boravio u Ateni. Ondje je prema Lukinu izvješću održao svoju najpoznatiju apologiju kršćanskoga monoteizma pred dobro informiranom politeističkom publikom. Kao obično, propovijedao je u sinagogi, ali i svakodnevno na agori. Atena je u to 
vrijeme smatrana kulturnim središtem svijeta, doimala se je kao veliki otvoreni muzej prepun religijskih objekata, a mnoštvo je idola izazvalo Pavlovu ogorčenost. Svojim raspravama na agori izazvao je pozornost i filozofski obrazovanih građana. Neke je čudilo spominjanje Isusa i uskrsnuća — to su shvatili kao nova božanstva. Nakon prijave morao se opravdati pred Areopagom, koji je bio nadležan za religijska pitanja. Iskoristio je priliku te je održao prvu kršćansku apologiju. Vijeće Areopaga nije našlo ništa sporno, govor je prekinut i nije podignuta nikakva optužnica.

\section{Literatura}

Benavides, Makayala (2019). The Romanization of Attic Ritual Space in the Age of Augustus. Tuscon: University of Arizona.

Bilde, Per (1993). The Jews in the diaspora of the Roman Empire. Nordisk judaistik / Scandinavian Jewish Studies, 14(2), 103-124.

Burden, Feffrey Christopher (1999). Athens Remade in the Age of Augustus: A Study of the Architects and Craftsmen at Work. Berkeley: University of California.

Curtius, Ernst (1891). Stadtgeschichte von Athen. Berlin: Weidmann.

Dickie, Matthew W. (2001). Magic and Magicians in the Greco-Roman World. London: Routledge.

Geagan, Daniel J. (1967). The Athenian Constitution after Sulla. Princeton: American school of classical studies at Athens.

Gruen, Erich S. (2002). Diaspora — Jews Amidst Greeks and Romans. Cambridge (Mass): Harvard University Press.

Hansen, Mogens Herman (1988). Three Studies in Athenian Demography. Copenhagen: The Royal Danish Academy of Sciences and Letters.

Hansen, Mogens Herman (2006). Studies in the Population of Aigina, Athens and Eretria. Copenhagen: The Royal Danish Academy of Sciences and Letters.

Hardin, Justin K. (2006). Decrees and drachmas at Thessalonica: An illegal assembly in Jason's house (Acts 17.1-10a). New Testament Studies, 52, 29-49.

Mitchell, Stephen (1999). The cult of theos hypsistos between pagans, Jews, and Christians. U: Polymania Athanassiadi i Micheal Frede (ur.), Pagan Monotheism in Late Antiquity (str. 81-148). Oxford: Clarendon.

Mitchell, Stephen (2010). Further thoughts on the cult of theos hypsistos. U: Stephen Mitchell i Peter van Nuffelen (ur.), One God: Pagan Monotheism in the Roman Empire (str. 167-208). Cambridge: Cambridge University Press.

Parigi, Caterina (2013). The Romanization of Athens: Greek identity and connectivity between Athens and Rome in the 1st century BC. U: SOMA 2012: Identity and connectivity: Vol. 1: BAR International series 258 (I) (str. 447-455). Oxford.

Robinson, O. F. (1995). The Criminal Law of Ancient Rome. London: Duckworth.

Schäfer, Peter (1995). The History of the Jews in the Greco-Roman World. London: Routledge.

Unnik, Willem Cornelius van (1993). Das Selbstverständnis der jüdischen Diaspora in der hellenistisch-römischen Zeit. Leiden: Brill.

Vidović, Marinko (2007). Pavlovski spisi: Uvod i osnove tumačenja. Split: Crkva u svijetu.

Winter, Bruce W. (2012). The enigma of imperial cultic activities and Paul in Corinth. David E. Aune i Frederick E. Brenk (ur.), Graeco-Roman Culture and the New Testament: Studies Commemorating the Centennial of the Pontificial Biblical Institute (str. 49-72). Leiden: Brill. 


\section{Paul in Athens}

Josip Talanga*

Summary

During his first European mission, Paul faced charges for allegedly practising magic at Philippi and, in Thessaloniki, for illegal gatherings and the refusal to recognize the Roman emperor. To avoid a possible conflict with the Roman authorities, he interrupted his mission and found refuge in Athens before his planned trip for Corinth. As usual, he established contact with the Jewish community but did not miss the opportunity to preach the gospel in the main square of the cultural center of the world at that time. Athens then looked like a large open-air museum filled with religious objects, i.e. idols, the sight of which caused Paul's indignation. With his daily discussions at the agora, he also attracted the attention of citizens educated in philosophy. To some, however, the subjects he addressed seemed strange - because he spoke of Jesus and the resurrection. Therefore, having been reported, he had to justify himself before the Areopagus which was in charge of religious matters. Paul seized the opportunity to deliver a speech which was, in fact, the first Christian apologia before well-informed polytheists. The Areopagus Council found nothing controversial in it, so no charges were brought against him.

Key words: Paul and the Roman authorities; Athenian agora in Paul's day; Paul before the Areopagus

* Josip Talanga, Ph.D., Full Profesor, Senior Fellow - Retired, Faculty of Philosophy and Religious Studies, University of Zagreb. Address: Jordanovac 110, 10000 Zagreb, Croatia. E-mail: josiptalanga@yahoo.com 